\title{
THE COPYRIGHT REPORT
}

In the spring of 1951 a committee was appointed by the President of the Board of Trade " to consider and report whether any changes are desirable in the law relating to copyright in literary, dramatic, musical and artistic works, with particular regard to technical developments and to the revised International Convention for the Protection of Literary and Artistic Works signed in Brussels in June 1948 , and to consider and report on related matters.",

That report has now been published* and will no doubt form the basis of legislation amending the Copyright Act of 1911 . It is a balanced, judicial document and study of it will repay anyone interested in the subject.

From the musician's point of view the most important matters are the period for which copyright protection should be granted; rights in gramophone records, cinematograph films and television programmes; performing rights, and fees charged for public performance of copyright works.

With regard to the first of these, the only notable change is the recommendation that in works of joint authorship the term of protection shall be calculated from the death of the last surviving author. Under the 1911 Act it subsists for 50 years from the death of the author who dies first or during the life of the author who dies last, whichever period is the longer. This has always seemed an anomaly. The amendment would bring the law in line with the Brussels Convention proposal.

The development of the gramophone record industry, as of course that of wireless broadcasting in all its forms, has greatly altered the situation that prevailed in I9II, and though the report recommends certain improvements and clarifications, it is interesting to note how well, in the main, the rgi I Act has stood the test of time.

It was the Berlin Convention of 1908 that originally gave to authors the right to authorize the mechanical reproduction of their works. This right was subsequently incorporated in our own law, but with the proviso that once a work has been recorded with the consent of the author, any other manufacturer may make other recordings of it without his consent (by what is called " compulsory licence"), subject to the payment of a prescribed royalty. The gramophone companies themselves enjoy copyright protection in so far as the copying and pirating of their records is forbidden, except that it is now recommended that the so-called " compulsory licence" shall only apply after a first recording has been made for sale. This point was previously in doubt. As regards the royalty on records, it was laid down in the I9I I Act that this could only be subject to revision (under an order by the Board of Trade, following a public enquiry) at intervals of fourteen years. The report recommends that the period should be reduced to five years.

As regards the length of time for which records and films remain protected by copyright, the report recommends that this shall be reduced from fifty to twenty-five years. It also recommends that the law be clarified to put it beyond doubt that copyright shall be vested in the maker of the original plate and that no copyright should be conferred on a record merely pressed in the United Kingdom from a matrix made outside the territory to which the Act applies. Another interesting point is the proposal that the definition of a "record " should

\footnotetext{
- Stationary Office, price $4 / 6$
} 
be amended in the revised Act so as to refer to the end-product, the ultimate representation of an acoustic effect, rather than to the means by which such an effect is produced. The present Act speaks of " contrivances by means of which sound may be mechanically 'performed or delivered' or 'reproduced' ". It is felt that the word "mechanically", if strictly construed, might not be appropriate to describe recent developments in the reproduction of sound, as for instance recording by wire or tape.

The use of music in films has created difficulties in recent years, when demands for royalties have been made upon film exhibitors and passed back by them to producers. Film producers, of course, would like to control the performing rights in music they have commissioned, at least in so far as performances of the film sound-track are concerned. The Performing Right Society, on the other hand, no less naturally desires to have all rights vested in itself, and the committee found that composers seemed not averse from this arrangement. The exhibitors, in their turn, claim that it is unreasonable to make them liable for the infringement of subsidiary rights in the films they have accepted in good faith from the distributors. No practical problem arises in Great Britain because here all cinemas are licensed by the Performing Right Society. Consequently no change in legislation is proposed, apart from a general recommendation which would have a bearing on the contractual relations between composers and film companies. But it is recognised that the difficulties mentioned above do exist in the international field and that it is beyond the scope of purely British legislation to settle them.

The general recommendation just referred to is " that where a work is created in pursuance of an express contract in writing providing that the copyright shall vest initially in some person other than the author, then the legal title shall so vest"'. This does not affect the fundamental principle that the author or originator of a work is the first owner of the copyright.

The section entitled " Performing and Performers' Rights" is one of the most intricate as well as one of the most important in the report. The activities of the Collecting Societies-The Performing Right Society, Phonographic Performance Ltd., The Mechanical Copyright Protection Society and the Sound Film Music Bureau--are defined and examined most lucidly. Reference is made to the degree of monopolistic control which may be exercised by the Performing Right Society, even though it is not, in the technical sense, a monopoly. The committee found little substance in most of the complaints to which they listened about the Society. They do recommend, however, that the fixing of tariffs payable to Collecting Societies of a monopolistic or quasi-monopolistic character should be subject to independent review. In support of this they quote from the evidence of the Chairman of the Performing Right Society, who said that there had been occasions in the past " when the Society would have welcomed an authoritative decision of the Board of Trade on a proposed tariff if that Department had the statutory power to give such a decision." What the committee propose is the setting up of a Standing Tribunal to decide disputes between collecting organisations controlling performing rights and broadcasting authorities controlling such rights on the one hand and would-be users of the works controlled on the other hand. They suggest that the Chairman of the Tribunal should be a person who holds or has held high judicial office, or at least a barrister of standing, appointed by the Lord Chancellor, and that the other members should be appointed by the Board of Trade.

A.G. 